\author{
Arkadiusz Urbanek \\ Uniwersytet Wrocławski
}

\title{
Bezradność wobec życia - dramat starości w cieniu samobójstwa
}

\author{
Helpless against life - tragedy of old age in the shade of suicide
}

Streszczenie. Artykuł koncentruje się na rekonstrukcji ostatnich dni życia ludzi w podeszłym wieku, którzy podjęli próbę samobójczą. Materiał źródłowy wykorzystany do analizy obejmował listy pożegnalne oraz wypowiedzi osób, które miały kontakt z samobójcą w ostatnim okresie życia. Przyjęty sposób operacjonalizacji danych to rekonstrukcja, której celem było odtwarzanie stanów emocjonalnych, zachowań czy wypowiedzi poszczególnych osób, w ostatnim okresie przed zamachem. Na podstawie omówienia sześciu przypadków zaprezentowano różnorodne konteksty subiektywnego postrzegania bezradności, jako osobistego doświadczenia człowieka starego. Tekst prezentuje analizę czynników ryzyka oraz mechanizmy zachowań suicydalnych, uwzględniając różnorodną ich specyfikę w ujęciu poszczególnych teorii samobójstw. Materiał źródłowy dostarcza wiedzy o niezwykle osobistej sferze życia i śmierci człowieka. Na jego podstawie możliwa jest eksploracja zorientowana na interpretację bezradności, w jakiej znalazł się człowiek przed zamachem samobójczym. Na podstawie zebranych informacji opisano także zmiany nastroju obserwowane w okresie poprzedzającym samobójstwo.

Słowa kluczowe: starość, samobójstwo, list pożegnalny, andragogika

Summary.The paper focuses on the reconstruction of the last days of the elderly who attempted suicide. The source material used for the analysis includes suicide notes and comments of persons who had contact with the suicide victim in the last period of life. The adopted method of data operationalisation is a reconstruction which aimed at recreating emotional states, behaviours, or comments particular of people in the last period before the suicide. Based on a description of six cases, various contexts of subjective perception of helplessness were presented as the personal experience of an elderly person. The text presents the analysis of risk factors and mechanisms of suicidal behaviours, taking into account their diverse specificity in the presentation of particular suicide theories. The source 
material provides knowledge about extremely personal sphere of human life and death. On its basis, it is possible to conduct an exploratory study focused on discovering the experience and interpretation of helplessness in which humans find themselves before a suicide act. Based on information collected, it also describes mood changes observed in the period preceding the suicide.

Keywords: old age, suicide, suicide note, andragogy

\section{Czynniki ryzyka zachowań samobójczych starzejących się ludzi}

Eksploracja naukowa zachowań suicydalnych dotyka kilku problemów o znaczeniu teoretycznym i praktycznym. Jednym z zagadnień jest ocena czynników ryzyka, które poprzedzają samobójstwo lub występują w trakcie zamachu na życie. Predykatory są klasyfikowane według kilku kryteriów. Jednym z nich jest wiek osób podejmujących próby samobójcze, który różnicuje ich doświadczenia życiowe oraz motywy działania. W okresie starości śmierć samobójcza wiąże się z dolegliwą, nieuleczalną chorobą, opisywaną jako stan nieodwracalny i wywołujący niekończące się cierpienie (Rogers, Bromely, McNally, Lester, 2007, s. 184-186; Bednarski, Urbanek, 2012, s. 134-187).

Pogłębione analizy statystyczne samobójstw pozwalają również dostrzec znaczenie kryteriów kulturowych czy etnicznych. Przykładowo w wielokulturowym społeczeństwie amerykańskim istotne różnice częstotliwości prób samobójczych odnotowano wśród społeczności czarnoskórej i przedstawicieli rasy białej. Badania w stanie Alabama skutkowały jednoznacznymi wnioskami, że zamachy na życie są częstsze wśród ludności białej, występowały w 18 przypadków na 100 tysięcy mieszkańców, podczas gdy wśród mieszkańców czarnoskórych i reprezentantów innych ras był to poziom 4,7 przypadków (Franks, Burnett, Evans, 2012, s. 35). Rozważając bezpośrednio predykatory samobójstwa osób w podeszłym wieku warto podkreślić, że w podgrupach etnicznych także zmieniała się częstotliwość ich występowania. Negatywne doświadczenia ludzi starych, odczuwających osamotnienie i izolację od najbliższej rodziny, częściej dotykały reprezentantów społeczności białej niż czarnoskórej. Przyczyną były różne warunki zamieszkania, ponieważ w rodzinach wielopokoleniowych gromadziła się głównie społeczność czarnoskóra, gdzie wspólnoty dziadków, dzieci i wnucząt odnotowano na poziomie $11,7 \%$. Wspólne, wielopokoleniowe zamieszkiwanie okazało się zjawiskiem rzadszym wśród społeczności białej (3,6\%) (Compton, Thom- 
son, Kaslow, 2005, s. 175-185), co generowało poczucie osamotnienia i braku użyteczności wśród seniorów.

Klasyfikacje czynników ryzyka samobójstw dostarczają wiedzy o chronologicznych zmianach społecznych. Tany Salvatore badając okoliczności zachowań suicydalnych wśród seniorów w USA wyróżnił czynniki demograficzne i społeczne. $Z$ jednej strony pojawił się wzrost liczby samobójstw w grupie osób urodzonych w okresie powojennego wyżu demograficznego lat 1946-1964. Wyż demograficzny spowodował, że naturalnie ta populacja stała się większa, zatem można przewidywać, że wystąpi w niej proporcjonalnie więcej zamachów samobójczych. Jednak z drugiej strony T. Salvatore analizując biografie osób w podeszłym wieku dostrzegał, że w okresie młodości mięli częstsze kontakty $\mathrm{z}$ alkoholem i narkotykami niż ich rodzice, wskazując na zmieniającą się specyfikę społeczeństwa. W efekcie ich organizmy w okresie starości są narażone na choroby somatyczne i psychiczne będące skutkiem uprzedniego stylu życia. Również zwrócił uwagę na znaczenie chorób cywilizacyjnych, które współcześnie dotykały osoby w podeszłym wieku częściej niż miało to miejsce w poprzednich pokoleniach. Zaliczono do nich cukrzycę, nadciśnienie, otyłość, problemy funkcjonowania układu mięśniowo-szkieletowego oraz depresję, wskazując tym samym na czynniki ryzyka samobójstw jako specyficzne dla współczesnego społeczeństwa (Salvatore, 2016, s. 2).

Dotychczasowe badania ilościowe umożliwiły zdefiniowanie szerszych katalogów, które systematyzują predykatory samobójstw wśród osób w podeszłym wieku, dostarczając niezwykle cennej wiedzy dla nauki i praktyki. Przykładowo Keith Hawton i Louise Harriss po przebadaniu 730 przypadków proponują systematyzację czynników ryzyka uwzględniając: choroby psychiczne (występujące u 46,1\% pacjentów), izolację społeczną (33,5\%), problemy w relacjach z rodziną $(29,4 \%)$, trudne relacje $\mathrm{z}$ partnerem życiowym (25,9\%), utratę bliskich (16,7\%) (2006, s. 572). Eve K. Mościcki wskazuje na dużą częstotliwość występowania chorób psychicznych wśród samobójców, które są diagnozowane w 90\% przypadków (Mościcki 2001, s. 315-316). Badania polskie potwierdzają, iż 90-95\% samobójców cierpiało na zaburzenia psychiczne, w $80 \%$ były to zaburzenia afektywne jak depresja, w $10 \%$ pojawiały się psychozy z kręgu schizofrenii (Rodziński, Rutkowski, Ostachowska, 2017, s. 517).

Obok kwestii indywidualnych katalog predykatorów samobójstwa uwzględnia relacje społeczne, wymieniając takie zagrożenia jak: trudności $\mathrm{w}$ pełnieniu ról społecznych, problemy w relacjach interpersonalnych, poczucie samotności wywołane rozwodem lub owdowieniem oraz brak zabez- 
pieczenia socjalnego (Kennedy, 2000; Sawyer, Williams, 2012; s. 84, 87). Jako symptomy zagrożenia wymieniane są: trudności adaptacyjne seniorów szczególnie w dynamicznie zmieniającym się otoczeniu, osłabienie mechanizmów radzenia sobie ze stresem i wyzwaniami życiowymi, które maleją wraz z wiekiem. Dodatkowo zagrażający jest brak wsparcia ze strony grupy społecznej oraz niepokój, utrata kontroli czy utrata sensu życia (Franks, Burnett, Evans, 2012, s. 32).

\section{Geneza zachowań suicydalnych w świetle teorii samobójstw}

Wśród różnorodnych poglądów na genezę i mechanizmy zachowań suicydalnych warto zaakcentować trzy koncepcje teoretyczne, istotne z uwagi na sytuację osób w podeszłym wieku. Jedno z ujęć proponuje Roy F. Baumeister (1990), opisując zachowanie samobójcy jako ucieczkę (Escape Theory) (Hochard, Heym, Townsend, 2017, s. 311). W myśl tej koncepcji sfery: emocjonalna, poznawcza i behawioralna człowieka ulegają zniekształceniom, natomiast proces tych zmian przebiega według kilku etapów. R.F. Baumeister interpretuje źródła zagrożenia samobójstwem w przeżywaniu nadmiernego stresu, początkowo wywołanego subiektywnym przekonaniem, że człowiek nie dorównuje oczekiwaniom, jakie stawia sam przed sobą. W konsekwencji doświadczanego stresu następuje wzrost poczucia winy za słabości i niedoskonałości. Pojawia się negatywny nastrój np. przygnębienie czy smutek, utrzymujący się przez dłuższy czas, bez wyraźnej poprawy. Tę tezę potwierdzają analizy treści listów pożegnalnych, w których zawarte są informacje o niemożności sprostania oczekiwaniom i standardom. Niekorzystne poczucie zawiedzenia sobą koresponduje z negatywnymi, wulgarnymi epitetami adresowanymi do siebie (szerzej analiza listów pożegnalnych w: Bednarski, Urbanek 2012, s. 134-187). W dalszych etapach procesu gotowości do samobójstwa negatywny stan emocjonalny wymusza zmiany w sferze poznawczej w taki sposób, aby pozwoliły na ucieczkę od tych przeżyć. Ucieczka następuje jednak poprzez irracjonalne sposoby myślenia, zawężenia poznawcze i brak zahamowań, powoduje, że samounicestwienie wydaje się łatwiejsze do wykonania (Stanley i in., 2016, s. 115; Ringel, 1987; Hołyst, 2002).

Rozważając zagadnienie bezradności człowieka starego wobec wyzwań życia, szczególną rolę odgrywa perspektywa teoretyczna (Hopelessness Theory), zaproponowana przez Aarona Becka (1985). Samobójstwo zostało zdefiniowane jako proces narastania poczucia beznadziei, który stopniowo podporządkowuje inne aspekty życia. Utrata nadziei wiąże się ze zubożeniem 
sfery emocjonalnej, motywacji, zdolności poznawczych, zachowań czy poczucia kontroli (Beck, 1986; Stanley i in., 2016, s. 115). Dodatkowo należy zwróci uwagę, że poczucie beznadziei stopniowo dotyka przyszłości i otoczenia społecznego. Przyszłość jawi się jako stan dramatyczny i niezmienny, nie przynosi ulgi czy pozytywnej zmiany. Podobnie otoczenie społeczne jest postrzegane jako nierozumiejące, a nawet wrogie, jest nieskuteczne w udzielaniu pomocy, o czym świadczą listy pożegnalne samobójców, właściwie w każdym wieku (Bednarski, Urbanek, 2012, s. 139-184).

Szczególną uwagę na cierpienie samobójcy zwraca Edwin Schneidman, kreując założenia teorii bólu psychicznego (Psychache Theory, 1993). W myśl tej koncepcji istnieją różne doświadczenia cierpienia, zarówno fizycznego, psychicznego czy cierpienia egzystencjalnego. Jest to przeżycie niezwykle subiektywne, które nie zawsze wprost wynika z określonej przyczyny, ale równocześnie jest tak dolegliwe, iż samobójca nie może go znieść. W takim stanie akt zamachu staje się formą ucieczki od przenikającego bólu, który zdaniem E. Shneidmana jest kluczowym motywem działania. Cierpieniu towarzyszą długotrwałe i wyczerpujące zaburzenia snu, ponieważ utrata nadziei w życiu i stany depresyjne stymulują bezsenność oraz występowanie koszmarów nocnych (Hochard, Heym, Townsend, 2017, s. 371). W analizach skoncentrowanych na ostatnich dniach życia samobójcy, a szczególnie człowieka starego, bardzo często pojawiają się informacje o bezsenności. Zgodnie z założeniami tej teorii jej obecność powinna być definiowana nie tylko jako bezpośredni efekt cierpienia wywołanego chorobą, ale także jako efekt pogarszającego się stanu emocjonalnego.

\section{Specyfika materiału źródłowego poddana badaniu rekonstrukcyjnemu}

Dominującym kierunkiem badań naukowych poświęconych sytuacji śmieci samobójczej są badania rekonstrukcyjne, prowadzone z dużą intensywnością od lat 50. XX wieku (O'Connor, Sheehy, 2003, s. 100). Badania rekonstrukcyjne stanowią zatem popularny kierunek operowania materiałami źródłowymi, jakimi są listy pożegnalne, notatki, opinie, wyniki badań medycznych czy wypowiedzi osób z otoczenia samobójcy. Podejmując analizę doświadczeń bezradności osoby dokonującej zamachu samobójczego, także zastosowano rekonstrukcję, która wykorzystywała dwa źródła danych: a) listy pożegnalne, jeżeli zmarła osoba pozostawiła taki dokument, b) wypowiedzi osób utrzymujących z nią relacje w ostatnim okresie życia. Część 
analizowanego materiału źródłowego pochodziła z opisów osób najbliższych i innych, np. świadków zamachu samobójczego, dlatego wprowadzała niejednorodne granice chronologiczne rekonstrukcji. Trudno sprecyzować odtwarzany okres czasu, ponieważ zależy od zachowanych dokumentów i zebranych informacji. Rekonstrukcja obejmuje ostatnie tygodnie czy dni życia, ale niekiedy źródła pozwalają odtworzyć tylko ostatnie godziny.

Analiza naukowa obu wykorzystywanych źródeł informacji obejmowała dwa aspekty: a) oznaczenie w tekście (listu lub zapisu wypowiedzi) czynników ryzyka zamachu, jakie ujawniły się w danej sytuacji, b) dokonanie interpretacji, jaką wyznaczonym czynnikom nadał sam samobójca przed śmiercią lub inne osoby po tym zdarzeniu. Procedura interpretacji koncentrował się na dwóch pytaniach: Jak osoby w podeszłym wieku interpretowały doświadczaną bezradność wobec życia w okresie poprzedzającym zamach samobójczy? Jakie zmiany nastroju w okresie poprzedzającym samobójstwo dostrzegało otoczenie społeczne samobójcy?

Dane źródłowe, które poddano analizie treści, stanowiły zapisy zawarte $\mathrm{w}$ aktach spraw zgromadzonych przez prokuratury na terenie dwóch sąsiadujących województw1, w toku postępowań wyjaśniających okoliczności śmierci samobójczej. W dokumentacji znalazły się m.in. notatki osobiste i listy pożegnalne oraz wyjaśnienia składane przez osoby, które miały bezpośredni lub pośredni kontakt z osobą zmarłą w ostatnim okresie życia. Zebrane źródła miały charakter archiwalny, obejmując zdarzenia zarejestrowane w okresie lat 2007-2009. Do analizy wybrano sześć przypadków osób (trzy kobiety i trzech mężczyzn), które podjęły próbę samobójczą w wieku 70, 76, 85 i 86 lat.

\section{Doświadczanie bezradności przez osoby stare a geneza zachowań samobójczych}

Bezradność stanowi jeden z czynników ryzyka zachowań suicydalnych, ale ma szczególne znaczenie $z$ uwagi na wielopoziomowy charakter tego doświadczenia. Bezradności towarzyszy narastająca bezsilność oraz skumulowanie indywidualnych i społecznych czynników ryzyka. Kształtuje się zatem negatywny nastrój człowieka, który w zniekształcony sposób postrzega swoją przyszłości jako zagrażającą, pełną cierpienia, niemożliwą do zniesie-

$1 \quad$ Z uwagi na zapewnienie anonimowości w publikacji materiałów źródłowych nie są podawane nazwy tych województw. 
nia i niezmienną. Bezradność jest częścią utrwalanego przekonania, że przyczyn trudnej sytuacji nie da się usunąć, a niepokój, cierpienie czy beznadzieja nigdy nie odejdą. Oczywiście poczucie bezradności może być także nagłym doświadczeniem afektywnym, gdy zaistniała sytuacja życiowa odbiera człowiekowi sens dalszej egzystencji.

Doświadczanie bezradności jest efektem splotu czynników o charakterze indywidualnym i społecznym, dlatego można ją interpretować jako kategorię nadrzędną. Aaron Beck (1986) odwoływał się do pojęcia beznadziei jako symptomu zagrożenia samobójstwem, jednak w przypadku sytuacji osób w podeszłym wieku, bezradność wobec życia zwraca uwagę na inny, ale ważniejszy obszar problemowy. Utrata nadziei na poprawę swego stanu jest obecna właściwie w doświadczeniach osób w każdym wieku, ale w przypadku osób starych dodatkowo pojawiają się czynniki obiektywne, które wyzwalają poczucie właśnie bezradności. Krzysztof Zajdel interpretując założenia kilku teorii starzenia się pisał, że człowiek wyłącza się z życia społecznego, tym samym musi zaakceptować, że ogranicza swój wpływ niektóre aspekty dotychczasowej aktywności. Naturalnie obniża się z wiekiem sprawność motoryczna i kondycja psychiczna, co obiektywnie ogranicza aktywności. Także wśród osób doświadczających beznadziei i bezradności nawet wobec codziennych sytuacji życiowych, trudno mówić o poziomie koherencji jako orientacji życiowej (Zajdel 2013, s. 240-241).

W analizowanych przypadkach samobójstw pojawiły się różnorodne czynniki, świadczące o narastającym zagrożeniu. Wśród predykatorów indywidualnych można wymienić: doświadczane cierpienie, nieustający ból, przekonanie o nieuleczalności choroby, utrzymujący się nastrój przygnębienia i smutku, bezsenność, lęk, niepokój, skrywanie emocji i przeżyć, beznadzieja. Również pojawiały się czynniki społeczne, głównie dotyczące relacji z ludźmi jak: brak zrozumienia, niechęć do bycia ciężarem dla innych, brak wyjścia z sytuacji, utrata bliskiej osoby, osamotnienie. Powyższe czynniki są jedynie wstępem do pogłębionej analizy, której cele koncentrują się na odczytywaniu zachowań, przemyśleń czy zmian nastroju człowieka. Powiązanie tych symptomów zagrożenia z kontekstem sytuacji i procesualnym sposobem działania stanowi pełny proces rekonstruowania okresu przed zamachem samobójczym.

$\mathrm{Na}$ podstawie zgromadzonych danych bezradność można interpretować w różnych kontekstach, jako:

a) niemoc w zmianie jakości życia,

b) utrata sensu dalszego życia, 
c) lęk przed sytuacją, w której człowiek się znalazł, mimo iż zagrożenie może być omamem wywołanym stanem psychicznym.

Jak wskazuje analiza predykatorów zachowań suicydalnych, osoby w podeszłym wieku dokonują prób samobójczych najczęściej z uwagi na problemy zdrowotne, którym towarzyszy cierpienie, a także obiektywny brak możliwości poprawy stanu zdrowia. Choroba (somatyczna i psychiczna) jawi się jako sytuacja nieodwracalna i nieuchronna, która w myśl koncepcji Roya F. Baumeistera (1990) może determinować samobójstwo jako formę ucieczki. Przez długi czas osoby są hospitalizowane, przechodzą operacje, latami zażywają leki, które i tak nie zmieniają dramatycznej dla nich sytuacji, dlatego w konsekwencji tracą nadzieję na poprawę. Splot czynników skłaniających do ucieczki przed niekończącym się cierpieniem obrazuje treść listu pozostawionego przez kobietę, która poniosła śmierć samobójczą w wieku 86 lat. W liście pożegnalnym wprost odniosła się właśnie do niemożności złagodzenia swojego cierpienia (Ilustracja 1), wobec którego była bezradna. W ostatnich dniach życia cierpiała na bezsenność i uskarżała się, że ból nie pozwala jej spać, a nawet operacja i pobyt w szpitalu od niego nie uwolniły.

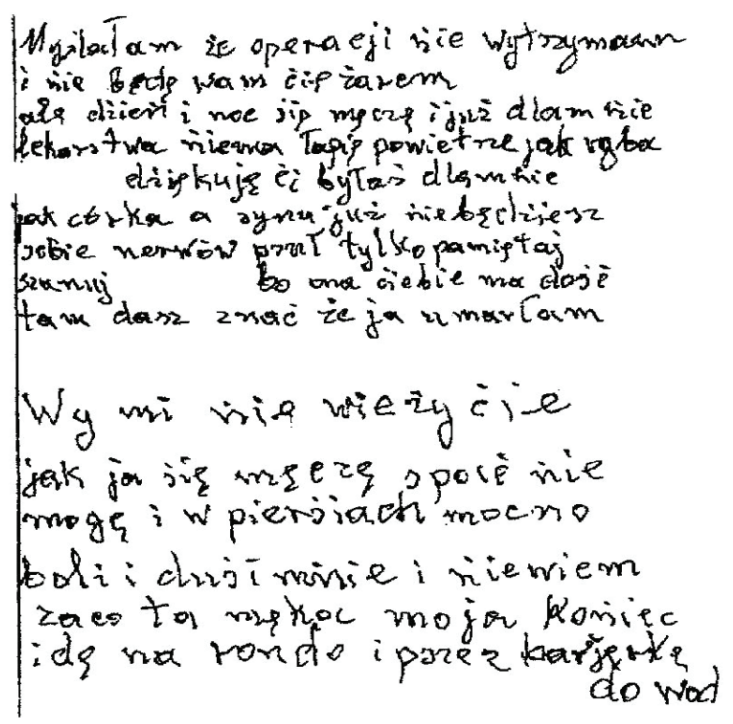

Ilustracja 1. List pożegnalny kobiety w wieku 86 lat.

Żródło: badania własne. 
Również przypadkowy świadek momentu dokonania zamachu na życie relacjonował, że kobieta krzyczała „nie mam już siły, mam wszystkiego dosyć". Jej ostatnie słowa potwierdzały treść $z$ listu, pozostawionego w pokoju przed wyjściem $z$ domu. Ważny jest także fakt, iż wykonywanie dramatycznej decyzji rozpoczęło się wczesnym rankiem, w okresie zimowym, gdy niewiele osób mogło zapobiec samobójstwu. Wśród zgromadzonych informacji zwraca uwagę także długotrwała bezsenność kobiety, zaakcentowana w liście pożegnalnym. Wiedzieli o niej bliscy kobiety (syn i synowa), z którymi mieszkała mówiąc, iż ten brak wypoczynku trwał od dłuższego czasu. Zgodnie z dotychczasowymi badaniami nad bezsennością samobójców jest ona interpretowana jako jeden z czynników ryzyka (Hochard, Heym, Townsend, 2017, s. 371).

Doświadczenie bezradności rozumianej jako niemoc w przezwyciężeniu cierpienia obrazuje przypadek 85-letniego mężczyzny, który w wyniku bólu wywołanego zwyrodnieniami kręgosłupa i dolegliwościami prostaty, zdecydował się na przedawkowanie tabletek przeciwbólowych i nasennych. Próbę samobójczą podjął w nocy, pod nieobecność pielęgniarki środowiskowej i rodziny, która się nim opiekowała, pozostawiając na stole list pożegnalny (Ilustracja 2).

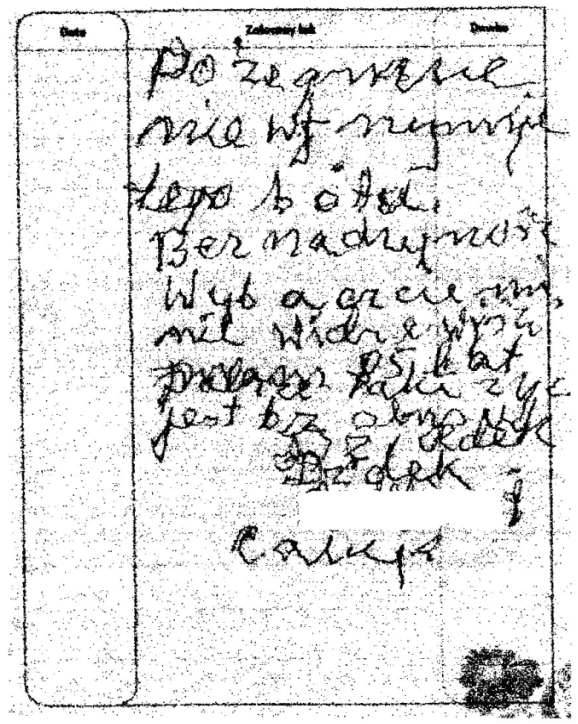

Ilustracja 2. List pożegnalny mężczyzny w wieku 85 lat.

Żródto: badania własne. 
Treść listu pożegnalnego wskazuje, iż motywem działania była ucieczka przed utrzymujący się latami bólem fizycznym, ale także mężczyzna wyraził $\mathrm{w}$ nim stan świadomości przed śmiercią. $\mathrm{W}$ trwającej latami sytuacji choroby przyszedł moment, gdy w liście napisał „nie wiedzę wyjścia”, zatem przyszłość niczego nie zmieni, a samobójstwo zostało zawężone do jedynego rozwiązania. Stan emocji i świadomości prawdopodobnie przez dłuższy czas kształtował proces decyzji o samobójstwie, o czym świadczy wybrany moment na dokonanie zamachu tak, aby uniknąć obecności osób, odwiedzających go w określonych porach dnia.

Inny wymiar doświadczanej bezradność człowieka starego wobec sytuacji życiowych opisuje przykład działania nagłego i afektywnego kobiety w wieku 76. Jej stan został wywołany utratą poczucia sensu życia. Rekonstruując okresu kilku godzin poprzedzających próbę samobójczą, kluczowym wyzwalaczem emocji i działania okazała się informacja o śmierci jedynego syna. Wystąpiło zdarzenie dramatyczne i zaskakujące, gdyź śmierć syna była niespodziewana. Ta informacja wywołała silne emocje, kobieta krzyczała, że nie ma sensu dalej żyć, że nie chce pozostać na świecie sama. Podjęła dwukrotnie próbę samobójczą w swoim mieszkaniu, a jedynie obecność brata i interwencja lekarzy spowodowały, iż próba samobójcza nie zakończyła się śmiercią. Należy podkreślić dwie ważne kwestie, na które to zdarzenie zwraca uwagę. Jedną z nich jest odmienny kontekst interpretowania bezradności, która w tej sytuacji jest stanem wobec nieodwracalnej śmierci syna. Doświadczenie straty angażowało emocje i sferę poznawczą, osoba krzyczała, że nie chce zostać sama na świecie.

Druga kwestia dotyczy znaczenia zachowań afektywnych poprzedzających próbę samobójczą. Zachowania nietypowe np. krzyk i działanie w amoku są sygnałami alarmującymi o zagrożeniu, ponieważ zwracają uwagę otoczenia społecznego, które stara się interweniować. Rozpoznawalne okazały się takie emocje jak wzburzenie, złości, wściekłość, na które zwrócił uwagę brat i dzięki temu udzielono pomocy. Jednak zdecydowanie częściej próba samobójcza jest poprzedzona emocjami wyzwalającymi mniejszą ekspresyjność. Bezradność jest doświadczeniem narastającym, ewoluuje w długim czasie, a wówczas następuje powolne utrwalanie negatywnego nastroju np. przygnębienia, smutku, beznadziei. Osoba wysyła zdecydowanie mniej sygnałów zwracających uwagę na konieczność pomocy, które pojawiają się nie wprost, stają się rozpoznawalne przez bliskich dopiero po fakcie zamachu samobójczego.

Przykłady niejednoznacznych sygnałów o zagrożeniu samobójstwem zawiera rekonstrukcja ostatnich dni życia mężczyzny w wieku 70 lat. Ana- 
liza materiału źródłowego zwraca uwagę na rozumienie bezradności, która pozostaje subiektywną, negatywną refleksją o życiu. Utrata sensu egzystencji niejednokrotnie stanowi osobistą tajemnicę, którą samobójcy przedstawiają fragmentarycznie w treści ostatniego listu, pozostawiając domysły, a nie wyjaśnienia. Potwierdza to treść listu pożegnalnego, który zawiera lakoniczną treść o przyczynie podjęcia zamachu na swe życie. (Ilustracja 3).

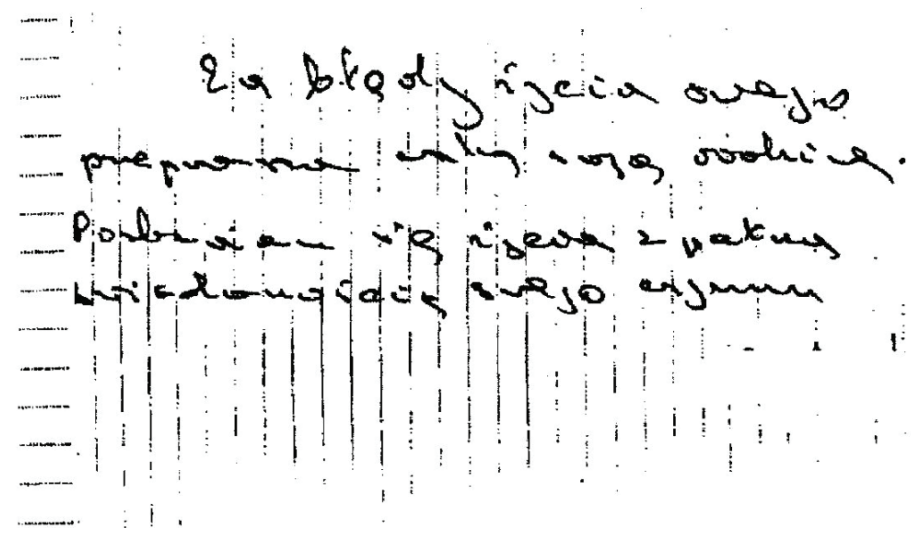

Ilustracja 3. List pożegnalny mężczyzny w wieku 70 lat.

Żródło: badania własne.

Z listu wynika, że w tle samobójczej śmierci była świadomość błędów popełnionych w życiu, jednak lakoniczna treść i informacje od najbliższych nie pozwoliły na wyjaśnienie, o jaką sytuację chodziło. Przygnębienie błędami życiowymi stało się dla niego niezmiernie dolegliwe, mimo iż prawdopodobnie nie wiązało się ono z realną przyczyną. Ten stan poczucia winy i samokrytycyzmu zwraca uwagę na dolegliwości depresyjne, których efektem były zachowania i przemyślenia trudne do logicznego wyjaśnienia. Rodzina określała sytuację majątkową, osobistą czy zdrowotną zmarłego jako bardzo dobrą. Także był osobą skrytą, nigdy nie ujawniał przed nimi przeżyć, które okazały się dramatyczne. W dniu poprzedzającym zamach samobójczy zmarły uczestniczył w uroczystościach świątecznych, omawiał plany zawodowe zięcia i nie wysyłał wprost sygnałów, pozwalających córce lub zięciowi rozpoznać zamiary ojca. Jedynie żona, która obserwowała męża przez dłuższy czas wiedziała, że od kilku miesięcy stał się „osowiały” i „smutny”, ale nie potrafiła wskazać zewnętrznej przyczyny tego stanu. Zgromadzone 
informacje pozwalają przypuszczać, że mężczyzna doświadczał silnych emocji w nocy, ponieważ dokonał zamachu samobójczego bardzo wczesną porą, a mimo to miał czas na pościelenie łóżka czy zostawienie listu pożegnalnego na stole, dlatego prawdopodobnie nie spał. Członkowie rodziny informowali, iż dotychczas nie występowały żadne zaburzenia kondycji psychicznej mężczyzny, nie był leczony na depresję i być może dlatego nie traktowano zmian nastroju jako przejawów choroby. Warto podkreślić, że mimo przygnębienia starał się utrzymywać aktywność, wykonywał codzienne czynności gospodarcze, pomagał w przygotowaniach świątecznych. Po jego śmierci najbliższa rodzina informowała, że taka aktywność odwracała ich uwagę do problemów emocjonalnych ojca, dlatego nie dostrzegali żadnych sygnałów zapowiadających zamach na życie.

Trzeci aspekt interpretowania bezradności człowieka wobec wyzwań życia, zwraca uwagę na zagadnienie pogarszającej się kondycji psychicznej w okresie poprzedzającym samounicestwienie. Przykładem bezradności wobec ogarniającego lęku jest historia życia mężczyzny w wieku 70 lat, pacjenta szpitala, który stracił życie w wyniku upadku z dużej wysokości. Należy podkreślić, iż zmarły nie był leczony psychiatrycznie, a somatycznie, natomiast załamanie kondycji psychicznej nastąpiło właściwie w ciągu jednej doby. Rekonstrukcja, jaka była możliwa na podstawie zgromadzonych źródeł, pozwoliła odtworzyć ostatnie trzy dni życia, opisując proces zmiany nastroju i zachowania mężczyzny. $Z$ relacji personelu medycznego i pacjentów wynika, że widoczne zmiany rozpoczęły się w nocy poprzedzającej śmierć, ponieważ mężczyzna nie spał tylko cała noc chodził po korytarzu, nic nie jadł. Wielokrotnie informował współpacjentów, że chce pójść do domu, a oni zauważyli nagły, silny niepokój i lęk przed pozostaniem w szpitalu, którego wcześniej osoba nie doświadczała. Personel medyczny dwukrotnie zatrzymał go przy drzwiach wejściowych, zapobiegając opuszczeniu szpitala. Rano w dniu śmierci, po rozmowach z lekarzem i podaniu leków uspokajających pacjent usiadł na krześle w szpitalnym korytarzu. Jednak czekając na przyjście w odwiedziny żony, wykorzystał nieobecność innych osób i zdecydował się na wyjście ze szpitala przez okno. Zabezpieczone ślady na ościeżnicy i parapecie świadczyły raczej o próbie ucieczki niż na świadomy zamiar pozbawienia siebie życia. Zdaniem biegłych sądowych zmiany nastroju i silny lęk przed zostaniem w szpitalu spowodował zniekształcenia percepcji rzeczywistości w takim stopniu, iż człowiek nie potrafił racjonalnie ocenić wysokości i związanego z nią niebezpieczeństwa. W opinii personelu medycznego zdarzenie miało charakter rutynowy, definiując tę sytuację jako częste zachowanie pacjentów, które wymagało podania leków uspokajających. Natomiast 
zaskakujące jest to, iż nikt nie zapytał dlaczego mężczyzna nagle postanowił pójść do domu i tak diametralnie zmienił zachowanie. Nie udało się dotworzyć informacji o tym, jak pacjent argumentował swoje obawy i motywy.

Lek przed chorobą i silne stany urojeniowe były także dostrzegane w przypadku kobiety w wieku 76 lat, która załamała się psychicznie po śmierci najbliższego jej brata. Od kilkudziesięciu lat egzystowała samotnie, gromadząc wokół siebie wąskie grono przyjaciół i rodziny, która pomagała w codziennych czynnościach. W tym gronie często informowała o swoim złym stanie zdrowia, dlatego umieszczono ją w szpitalu, który po kilku dniach opuściła na własne żądanie. Badania medyczne nie potwierdziły, aby stan zdrowia wyraźnie różnił się od kondycji adekwatnej dla jej wieku, ale mimo to kobieta była przekonana o swej nieuleczalnej chorobie. Podejrzewano, iż jest to wynik silnych urojeń, które nasiliły się w ostatnich miesiącach, czyli po śmierci brata. Informacje od bratanka potwierdziły, że kobieta była przekonana o swej chorobie. Przed śmiercią dzwoniła do niego i nalegała na przyjazd, natomiast w jego odczuciu ostatnia rozmowa była formą pożegnania się. Na tydzień przed zamachem samobójczym przekazała mu pamiątki rodzinne, zaś po kilku dniach bez informowania kogokolwiek o swych planach, skoczyła z dużej wysokości.

\section{Zmiany nastroju samobójców obserwowane przez otoczenie społeczne}

Selekcjonując informacje uzyskane od bliskich, najczęściej opisywali oni zmiany w sferze emocjonalnej, która generalnie w okresie przed śmiercią uległa znacznemu pogorszeniu w kierunku emocji negatywnych (Tabela 1).

Badania dotyczące zachowań suicydalnych prezentują odmienne sposoby zachowań osób w okresie poprzedzającym śmierć. Niektórzy pozorują aktywność, starają się podtrzymywać wrażenie zaangażowania w relacje rodzinne. Jednak, jak wynika $\mathrm{z}$ omawianych historii przypadków, zdecydowanie trudniej kamuflować spadek nastroju. Zgromadzone dane pozwalają wnioskować, że negatywne emocje, jak smutek czy przygnębienie, okazały się najbardziej czytelne i zwracały uwagę najbliższych, dlatego specjaliści pracujący wśród seniorów powinni być przygotowani do obserwowania tej sfery. 
Tabela 1. Zestawienie informacji o zmieniającym się nastroju samobójców w rekonstruowanym okresie życia.

\begin{tabular}{|c|c|c|c|}
\hline L.p. & $\begin{array}{l}\text { Płeć } \\
\text { Wiek }\end{array}$ & Ocena cech osoby & $\begin{array}{l}\text { Zaobserwowane zmiany w ostatnich } \\
\text { dniach życia }\end{array}$ \\
\hline 1 & $\begin{array}{l}\text { kobieta } \\
86 \text { lat }\end{array}$ & $\begin{array}{l}\text { dobre relacje z synem i synową, } \\
\text { osoba nie była leczona psychia- } \\
\text { trycznie, zły stan zdrowia }\end{array}$ & $\begin{array}{l}\text { doświadczany silny ból, bezsenność, złe sa- } \\
\text { mopoczucie, niechęć do bycia ciężarem dla } \\
\text { bliskich, pogorszenie kondycji psychicznej po } \\
\text { operacji i powrocie ze szpitala }\end{array}$ \\
\hline 2 & mężczyzna 85 lat & $\begin{array}{c}\text { osoba schorowana, cierpiąca, za- } \\
\text { pewniona opieka, bliskie kontakty } \\
\text { z rodzina, człowiek nie leczył się } \\
\text { psychiatrycznie, nie podejmował } \\
\text { prób samobójczych }\end{array}$ & $\begin{array}{c}\text { silny ból fizyczny, narastające przygnębienie } \\
\text { sytuacją, w jakiej się znalazł }\end{array}$ \\
\hline 3 & $\begin{array}{l}\text { kobieta } \\
76 \text { lat }\end{array}$ & & $\begin{array}{l}\text { doświadczany stan silnego wzburzenia, } \\
\text { nagły, wielokrotny atak autoagresywny }\end{array}$ \\
\hline 4 & mężczyzna 70 lat & $\begin{array}{l}\text { osoba nie była leczona psy- } \\
\text { chiatrycznie ani odwykowo, bez } \\
\text { konfliktów w rodzinie, aktywny } \\
\text { w sprawach rodzinnych, bez } \\
\text { problemów finansowych, osoba } \\
\text { lubiana }\end{array}$ & $\begin{array}{c}\text { osoba skryta, w okresie przed śmiercią } \\
\text { smutna i osowiała }\end{array}$ \\
\hline 5 & mężczyzna 70 lat & $\begin{array}{l}\text { osoba pogodna, żona opisywała } \\
\text { go jako osobę wesołą }\end{array}$ & $\begin{array}{l}\text { w nocy przed śmiercią osoba zamknięta, } \\
\text { izolująca się od innych, mężczyzna z nikim } \\
\text { nie rozmawiał, brak snu, silny niepokój }\end{array}$ \\
\hline 6 & $\begin{array}{l}\text { kobieta } \\
76 \text { lat }\end{array}$ & $\begin{array}{l}\text { osoba samotna, wspomagana } \\
\text { przez dalszą rodzinę, pogodna, } \\
\text { utrzymując kontakty tylko z wą- } \\
\text { skim gronem znajomych }\end{array}$ & $\begin{array}{c}\text { doświadczana apatia zwiazzana z przekona- } \\
\text { niem o nieuleczalnej chorobie, kompulsywne } \\
\text { rozmyślanie o złym stanie zdrowia, załamanie } \\
\text { po śmierci brata }\end{array}$ \\
\hline
\end{tabular}

Źródło: badania własne.

Z drugiej strony przywołane historie wskazują, że osoby cierpiące same informują o swych zamiarach, nie ukrywają planów samobójczych, a raczej przygotowują otoczenie na sytuację zamachu na swe życie. Przykładem jest kobieta (86 lat), która w rozmowach z bliskimi podejmowała temat bezradności wobec cierpienia i swych planów samobójczych. Takie komunikaty formułowane wprost wiązały się z poczuciem bycia ciężarem dla rodziny (Ilustracja 1). Kilka dni wcześniej informowała synową o tym, że chciałby już nie żyć, a skoro przeżyła operację, to sama pozbawi się życia, aby nie być ciężarem dla innych. Podobnie w bezpośredni sposób komunikowała kobieta w wieku 76 lat, która targnęła się na życie w silnym afekcie, krzycząc, 
że nie chce żyć. Równocześnie można odnotować, że niektóre osoby uprzedzały o swych zamiarach w zakamuflowany sposób. W zawoalowanej formie o swych planach samobójczych informowała kobieta w wieku 76 lat, która na tydzień przed śmiercią zaprosiła bratanka i przekazywała mu pamiątki rodzinne. W jego przekonaniu sposób zachowania i treść rozmowy świadczyły o chęci pożegnania się z bliską osobą, chociaż te intencje stały się czytelne już po śmierci. Plany pozbawienia się życia są również ukrywane, często bliscy nie potrafią wskazać pośrednich ani bezpośrednich sygnałów o zagrożeniu. Dopiero po fakcie analiza zmian nastroju rodzi pewne skojarzenia, na podstawie których rodzina interpretuje zamiary zmarłych, odczytując w nich objawy zmian.

\section{Refleksje końcowe}

Przywołane historie osób w ostatnim okresie przed próbą samobójczą, zwracają uwagę na obszary wciąż niszowe dla nauki i praktyki. Pojawiają się ciekawe wątki teoretyczne i empiryczne, które służą budowaniu systemu wczesnej profilaktyki środowiskowej. Wiedza o czynnikach ryzyka, zmianach w nastroju czy świadomość nieprzewidywalnych zachowań człowieka uciekającego przed cierpieniem, stają się częścią obligatoryjnych kompetencji zawodowych. Przedstawiciele służb medycznych, socjalnych czy animatorzy aktywności seniorów, dysponują szerokimi możliwościami prowadzenia rozmów, które dostarczają ważnych informacji. Wywiady diagnostyczne mogą alarmować o zagrożeniu, świadczą o narastającym niepokoju, beznadziei czy bezradności, zwracając uwagę specjalistów na niepokojące aspekty, pod warunkiem, iż dysponują wiedzą w tym zakresie. Dlatego nieocenionym źródeł wiedzy są rekonstrukcje zdarzeń samobójczych i ich okoliczności, które informują o różnorodnych kontekstach sytuacyjnych, w jakich ujawniają się mechanizmy zachowania suicydalnego.

Z drugiej strony rozmowy z seniorami prowadzone przez osoby świadome uwarunkowań suicydalnych, stanowią szansę na stymulowanie tych sfer emocji, procesów poznawczych czy działań, które stanowią przeciwwagę dla predykatorów zagrożenia. Dla praktyki istotne są wnioski dotyczące subiektywnego rozumienia przyszłości człowieka, przejawy spadku nastroju, negatywne interpretowanie celów życiowych, równocześnie z inicjatywą kształtowania takich programów wsparcia, które mogłyby w porę je kompensować. 
Niszą naukową jest eksploracja świata duchowego osób starych. Duchowość można interpretować w wąskim zakresie jako religijność, przywiązanie do wspólnoty i zasad wiary. Przywołane badania amerykańskie Marka M. Leach'a potwierdziły związki pomiędzy aktywnością religijną w społeczności wiernych a ochroną przed utratą sensu życia. Podobnie religijność kształtuje sferę powinności człowieka i zasad, które nadają sens doświadczeniom doczesnym. Dlatego działalność związków religijnych wśród osób starych jest jednym z ważniejszych kierunków profilaktycznych. Wśród rozważanych przypadków ta sfera została zupełnie pominięta, bliscy nie informowali o niej, co potwierdza tezę, ze religijność była kwestią poboczną, niedostrzeganą.

W szerszym znaczeniu duchowość jest immanentną częścią starości człowieka i nie obejmuje tylko praktyki religijnej. Elżbieta Dubas pisała, że sama starość jest doświadczeniem duchowym człowieka, bez duchowości staje się ona niezrozumiała i niemożliwa do zaakceptowania (Dubas, 2013, s. 140). Pojawia się zatem kolejna nisza naukowa, ponieważ brakuje badań tej sfery życia. Eksploracje naukowe i diagnostyczne badania przesiewowe w środowiskach osób starych nie mogą bazować tylko na ocenie występowania znanych z literatury czynników ryzyka samobójstw. Naturalną częścią starości są przeżycia egzystencjalne jak: doświadczenia choroby, cierpienia, niepełnosprawności, bolesna samotność, śmierć innych czy nadchodząca śmierć własna (tamże, s. 140). Zatem trudności życiowe, a nawet doświadczana bezradności wobec wyzwań życia są immanentną częścią tego okresu życia. $Z$ tego powodu nauka powinna podjąć pogłębione analizy teoretyczne i empiryczne wokół procesów autokreacji człowieka starego (tamże s.150). To one byłyby buforem przed beznadzieją i bezradnością, kształtując bogatą sferę duchową. Tego typu badania również służą kreowaniu teorii profilaktyki samobójstw. Autokreacja i dojrzałość duchowa pozostają w związku z jakością kondycji emocjonalnej człowieka starego, ale w przypadku osób z grupy ryzyka takich związków nie poddawano dotąd eksploracji.

\section{Bibliografia}

Beck A. T. (1986), Hopelessness as a predicator of eventual suicide, „Annals of the New York Academy of Science” vol. 487, p. 90-96.

Baumeister R. F. (1990), Suicide as escape form self, „Psychological Review” vol. 97/1, p. 90-113. 
Bednarski L., Urbanek A. (2012), Śmierć samobójcza - perspektywa kryminalistyczna i pedagogiczna, Wydawnictwo Impuls, Kraków.

Dubas E. (2013), Starość znana i nieznana - wybrane refleksje nad współczesna starościq, „Rocznik Andragogiczny” nr 20, s. 135-152.

Durkheim E. (1897), Suicide: A study in sociology, Routledge, London

Compton M. T., Thompson N.J., Kaslow N. J. (2005), Social environment factors associated with suicide attempt among low-income African Americans: The protective role o family relationships and social support, „Social Psychiatry \& Psychiatric Epidemiology", vol. 40, p. 175-185.

Franks R., Burnett D. O., Evans R.R. (2012), Risk Factors and Prevention Strategies for Siucide Among the Eldery, „Alabama Counseling Association Journal” vol. 38/2, p. 32-42.

Goldblatt M. J., Ronningstam E., Schechter M., Herbstman B., Maltsberger J. T. (2016), Suicide as escape from psychotic Panic, „Bulletin of the Menninger Clinic" vol. 80/2, p. 131-145.

Greenleee K., Hyde P. S. (2014), Suicide and Depression in Older Adults: Greater Awarness Can Prevent Tragedy, "Journal of the American Society on Aging” vol. 38/3, p. 23-26.

Hawton K., Harriss L. (2006), Deliberate self-harm in people aged 60 years and over: characteristics and outcome of 20-year kohort, „International Journal of Geriatric Psychiatry" vol 21, p. 572-581.

Hołyst B. (1983), Samobójstwo - przypadek czy konieczność, Wydawnictwo Naukowe PWN, Warszawa.

Hołyst B. (2002), Suicydologia, Wydawnictwo Lexis Nexis, Warszawa.

Hochard K. D., Heym N., Townsend E. (2017), Investigating the Interaction Between Sleep Symptoms of Arousal and Acquired Capability in Predicting Suicidality, „Suicide and Life-Threatening Behavior" vol. 47/3, p. 370-381.

Joiner T. E. (2005), Why people die by suicide, Harvard University Press, Cambridge MA.

Kennedy G. J. (2000). Geriatric Mental Health Care: A treatment guide for professionals, The Guilford Press, New York.

Leach M. M. (2006), Cultural diversity and suicide: Ethnic, religious, gender, and sexual orientation perspectives, The Haworth Press, New York.

Mościcki E. K. (2001), Epidemiology of completed and attempted suicide: toward a framework for prevention, „Clinical Neuroscience Research” vol. 1, p. 310-323.

Nordentoft M. (2007), Prevention of suicide and attempted suicide in Denmark. Epidemiological studies of suicide and intervention studies in selected risk groups, „Doctor of Medical Science" October vol. 5, p. 306-369

Oquendo M.A., Currier D., Lius S., Hasin D., Grant B., Blanco C. (2010), Increased risk for suicidal behavior in co-mordib bipolar disorder and alcohol use disorders, „Journal of Clinical Psychiatry” vol. 71/7, p. 902-909.

Ringel E. (1987), Gdy życie traci sens. Rozważania o samobójstwie, tłum. E. Kaźmierczak, Wydawnictwo Glob, Szczecin. 
Rodziński P., Rutkowski K., Ostachowska A. (2017), Progresja myśli samobójczych do zachowań samobójczych w świetle wybranych modeli suicydologicznych, „Psychiatria Polska" nr 51/3, s. 515-530.

Rogers J. R., Bromely J. L., McNally J., Lester D. (2007), Content analysis of suicie notes as a test of the motivational component of the existential-constructivist model of suicie, „Journal of Counseling \& Development” vol. 85, p. 182-188.

Salvatore T. (2016)., Suicide Risk in Older Adults: A Growing Challenge for Law Enforcement, „FBI Law Enforcement Bulletin” vol. 2/11, p. 2-6 .

Sawyer P., Williams B.R. (2012), Counseling older adults at risk of suicide: recognizing barriers, reviewing strategies, and exploring opportunities for intervention, „Alabama Counseling Association" vol. 38/2, p. 80-103.

Shneidman E.S. (1993), Suicide as psychache: A clinical approach to self-destructive behavior, Lason Aronson, Lanham MD.

Stanley I. H., Hom M.A., Rogers M. L., Hagan C.R., Joiner T.E. (2016), Understanding suicide among older adults: a review of psychological an sociological theories of suicide, „Aging \& Mental Health” vol. 20/2, p. 113-122.

Van Orden K. A., Witte T.K., Cukrowicz K. C., Braithwaite S.R., Selby E.A. (2010), The interpersonal theory of suicide, „Psychological Review” vol. 117(2), p. 575-600 .

Zajdel K. (2013), Jakość życia nauczycieli emerytów i rencistów, „Rocznik Andragogiczny" nr 20, s. 237-252. 